\title{
The art and science of preventing and treating HIV disease in children: a life cycle approach Elaine Abrams
}

Address: Department of Paediatrics, Columbia University College of Physicians and Surgeons, New York, NY 10032, USA from Fifth Dominique Dormont International Conference. Mother-to-child transmitted viral diseases: from transmission to children care Paris, France. 26-28 March 2009

Published: 22 July 2009

Retrovirology 2009, 6(SuppI I):L4 doi:I0.II86/I742-4690-6-SI-L4

This abstract is available from: http://www.retrovirology.com/content/6/SI/L4

(C) 2009 Abrams; licensee BioMed Central Ltd.

Dr Abrams will review current scientific knowledge in the area of pediatric HIV infection from infancy through adolescence and will identify critical gaps that significantly impact successful care of children with HIV disease. She will explore three interconnected themes: evolution of physical and psychological development throughout childhood; the relationship between the child and her family; and importance of psychological, behavioral, and social issues as they affect successful treatment of the HIV infected child as well as vulnerability of the uninfected adolescent to acquisition of HIV infection. Combining experiences from HIV programs in resource rich and resource constrained settings, Dr. Abrams will highlight a number of pressing questions warranting urgent scientific inquiry. 